УдК 657.47

\title{
I. A. Максимчук,
}

к. пед. наук, дочент кафедри управління підприємницькою та туристичною діяльністю,

Ізмаїльський державний гуманітарний університет

ORCID ID: 0000-0002-4361-3507

T.K. Memiль,

к. е.н., дочент кафедри управління підприємничькою та туристичною діяльністю,

Ізмаїльський державний гуманітарний університет

ORCID ID: 0000-0002-4553-4343

DOI: $10.32702 / 2306-6814.2021 .16 .46$

\section{ОРГАНІЗАЦІЯ УПРАВ АНСЬКОГО ОБАІКУ В ІНФОРМАЦІЙНОМУ ПРОСТОРІ ПІАПРИЕМСТВА}

\author{
I. Maksymchuk, \\ $\mathrm{PhD}$ in Pedagogical Sciences, Associate Professor of the Department \\ of Business and Tourism Management Izmail State University \\ T. Metil, \\ $\mathrm{PhD}$ in Economics, Associate Professor of the Department of Business \\ and Tourism Management, Izmail State Humanities University
}

\section{ORGANIZATION OF MANAGEMENT ACCOUNTING IN THE INFORMATION SPACE OF THE} ENTERPRISE

У статті досліджено організація управлінського обліку в інформаційному просторі підприємства. Метою статті є системне дослідження, критична оцінка теоретичних положень та діючої практики управлінського обліку. Досліджено елементи системи бухгалтерського управлінського обліку на підприємстві. Проаналізовано комплекс елементів управлінської облікової політики як сукупності трьох секторів: організаційний, технічний та методичний. Побудовано класифікацію внутрішніх стандартів управлінського обліку за трьома ієрархічними рівнями: інструктивно-методична документація; регуляторна документація; регулююча документація. Проаналізовано етапи формування внутрішніх стандартів управлінського обліку: розробка загальних класифікацій та довідкових книг класифікації; розробка структури управління рахунками; формування системи управлінської звітності. Розглянуто перспективи подальших досліджень: розробка відповідної документації для кожного сектору облікової політики управлінського обліку, розробка графікудокументації управлінського обліку тощо.

The article examines the organization of management accounting in the information space of the enterprise. Today, Management accounting acts as an information foundation for management processes, which allows solving strategically important tasks. The main purpose of this type of accounting should be considered the provision of high-quality information for the purpose of making predictive and operational management decisions. Management accounting provides a wide range of opportunities for generalization, processing and analysis of information coming from the main structural elements of the enterprise management system. The purpose of the article is a systematic 
study, a critical assessment of the theoretical provisions and current practice of management accounting. The elements of the accounting management accounting system at the enterprise are studied. The complex of elements of management accounting policyas a combination of three sectors is analyzed; organizational, technical and methodological. The classification of internal management accounting standards is constructed according to three hierarchical levels: instructional and methodological documentation; regulatory documentation; regulatory documentation. The stages of the formation of internal management accounting standards are analyzed: the development of general classifications and classification reference books; the development of an account management structure; the formation of a management reporting system. In the practical activities of enterprises, there are various variants of definitions: accounting rules, accounting and budget management rules, accounting funds management, internal standards, corporate standards, and the like. Today, Management accounting acts as an information foundation for management processes, which allows solving strategically important tasks. The main purpose of this type of accounting should be considered the provision of high-quality information for the purpose of making predictive and operational management decisions. Management accounting provides a wide range of opportunities for generalization, processing and analysis of information coming from the main structural elements of the enterprise management system. The prospects for further research are considered: the development of appropriate documentation for each sector of the accounting policy of management accounting, the development of a schedule of documentation of management accounting, and so on.

Ключові слова: управлінський облік, політика, процедура, зВітність, інформаційний фундамент.

Key words: management accounting, policy, procedure, reporting, information foundation.

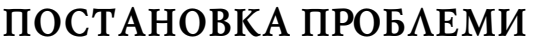

Сьогодні управлінський облік виступає в ролі інформаційного фундаменту процесів управління, який дозволяє вирішувати стратегічно важливі завдання. Основним призначенням цього виду обліку необхідно вважати надання якісної інформації з метою прийняття прогнозних та оперативних управлінських рішень. Управлінський облік надає широкий спектр можливостей для узагальнення, обробки та аналізу показників, що надходять з основних структурних елементів системи управління підприємством.

У нинішньому турбулентному періоді, коли сингулярно змінюються економічні умови, необхідно використовувати гнучкі інструменти та підходи. Вимоги до зменшення витрат та підвищення ефрективності, що спричинило боротьбу за конкурентоспроможність на світових ринках, кардинально змінюють аспекти управління підприємствами.

Ці аспекти слід враховувати при фрормуванні системи управлінському обліку. Відображення сучасних економічних теорій у управлінському обліку допоможуть принести нові уявлення, які у кінцевому підсумку, допоможуть вирішити критичні проблеми підприємств.

\section{АНА $\Lambda$ IЗ ОСТАНHIX АОС $\Lambda$ ІАЖЕНЬ І ПУБ $А$ АЦІЙ.}

У сучасних дослідженнях щодо організації управлінського обліку на підприємствах існують різноманітні наукові погляди. Розглянемо більш детально українську наукову школу.
Костякова А.А. дослідила методологічні основи управлінського обліку в науковій літературі з питань невизначеності: різні тлумачення змісту термінів "управлінський облік", "облік витрат", "виробничий облік", розглянула взаємозв'язок даних категорій на сучасному етапі їх розвитку [1].

Дерій В.А. та Гуменна-Дерій М.В. рекомендують, щоб кожне функціонуюче підприємство виробило власну Концепцію ведення управлінського обліку та документально їі закріпило у "Положенні про управлінський облік в підприємстві" або у "Наказі про облікову політику підприємства" [2].

Турова Л.Л. та Костюнік О.В. визначають три етапи впровадження системи управлінського обліку [3]. Перший етап включає: постановку мети, планування і прогнозування, фрормування інформаційної бази, диференціацію витрат, аналіз і контроль, коригування планів. Другий етап включає організацію системи управлінського обліку: опрацювання набору підконтрольних показників, розрахунок і аналіз основних показників у оперативному режимі, організація інфоомаційного забезпечення, виявлення неприпустимих відхилень та виявлення "вузьких місць". Третій етап передбачає налагодження регулярних процедур оперативному режимі: документування, моніторинг, інформаційне та економічне моделювання, економічний аналіз.

Сирцева С.В., Кушнірук В.С. та Бондаренко І.О. констатують, що за допомогою управлінського обліку контролінг дає змогу вивести управління підприємством на якісно новий рівень, інтегруючи, координуючи та спря- 
мовуючи діяльність різних підрозділів підприємства на досягнення оперативних та стратегічних цілей [4].

Мазіна O.І. визначила, що дотримання глобальних принципів управлінського обліку дозволяє досягти зростання вартості бізнесу та забезпечує сталий розвиток економіки [5]. Автор досліджує компетенції фрахівців, які приймають управлінські рішення та забезпечують зростання вартості бізнесу.

Костюченко В.М., Малиновська А.М. та Мамонова А.В. побудували модель концептуальної основи управлінського обліку на основі глобальних принципів управлінського обліку [6]. Це сприятиме досягненню стратегічних цілей, спрямованих на збереження і приріст вартості підприємства та задоволення інформаційних запитів менеджерів для підвищення ефективності діяльності в умовах перманентних змін.

Яременко Л.М. та Пономаренко Я.А. проаналізували основні переваги та недоліки основних систем управлінського обліку та показані найбільш типові проблеми, що виникають у сучасних умовах при впровадженні управлінського обліку на підприємствах України [7]. Запропоновано шляхи вирішення цих проблем, які $є$ передумовою успішної роботи та виживання підприємств в умовах вільної конкуренції, а також зростання їх економічного потенціалу.

Волковська Я.В. встановила доцільність та недоліки тих чи інших етапів організації управлінського обліку, необхідність організації управлінського обліку на трьох

Таблиця 1. Елементи управлінської облікової політики

\begin{tabular}{|c|c|c|}
\hline Елементи & Регуляторні документи & Результати \\
\hline \multicolumn{3}{|c|}{ Організаційний сектор } \\
\hline Організаційна структура & $\begin{array}{l}\text { Положення про організаційну структуру. } \\
\text { Описи робіт, що відображають } \\
\text { перерозподіл функціональних обов'язків } \\
\text { працівників }\end{array}$ & $\begin{array}{l}\text { Визначення організаційної структури підприємства, } \\
\text { підрозділів, їх функцій та діяльність. } \\
\text { Відповідні основи структурних рішень для побудови } \\
\text { основної архітектури всіх підсистем управлінського обліку }\end{array}$ \\
\hline Фінансова структура & Положення про фінансову структуру & $\begin{array}{l}\text { Вибір центрів відповідальності підприємства. } \\
\text { Класифікація центрів (витрати, доходи, прибуток, } \\
\text { маржинальній дохід, інвестиції) }\end{array}$ \\
\hline $\begin{array}{l}\text { Бюджетно-фінансова } \\
\text { структура }\end{array}$ & $\begin{array}{l}\text { Положення про бюджетування. } \\
\text { Положення про винагороду }\end{array}$ & $\begin{array}{l}\text { Проєкція фінансової структури за різними бюджетами } \\
\text { Класифікатор бюджетування (MDD, CFB, бюджети } \\
\text { накладних витрат) }\end{array}$ \\
\hline $\begin{array}{l}\text { Повноваження та } \\
\text { структура } \\
\text { бухгалтерського обліку } \\
\text { та контролю } \\
\end{array}$ & $\begin{array}{l}\text { Положення про бухгалтерський облік та } \\
\text { контроль управління. } \\
\text { Інструкції з управління персоналом }\end{array}$ & Відповідальний за підтримку управлінського обліку \\
\hline \multicolumn{3}{|c|}{ Технічний сектор } \\
\hline $\begin{array}{l}\text { Внутрішній потік } \\
\text { стандартів документації }\end{array}$ & $\begin{array}{l}\text { Положення про взаємодію підрозділів у } \\
\text { системі виробництва та управління }\end{array}$ & Графік потоку документації \\
\hline $\begin{array}{l}\text { Опис структур даних для } \\
\text { комплексної } \\
\text { автоматизації } \\
\text { управлінського обліку }\end{array}$ & Технічне завдання & Положення, підготовлені до затвердження \\
\hline $\begin{array}{l}\text { Формування управління } \\
\text { системою рахунків }\end{array}$ & $\begin{array}{l}\text { Робочий план рахунків управлінського } \\
\text { обліку }\end{array}$ & $\begin{array}{l}\text { Кодифікатор рівня аналітичних рахунків. } \\
\text { Зв'язок рахунків фінансового та управлінського обліку }\end{array}$ \\
\hline $\begin{array}{l}\text { Опис взаємодії з } \\
\text { бухгалтерськими } \\
\text { (фінансовими) } \\
\text { документами } \\
\end{array}$ & $\begin{array}{l}\text { Положення взаємодії системи рахунків } \\
\text { управлінського обліку та } \\
\text { бухгалтерського обліку }\end{array}$ & $\begin{array}{l}\text { Співвідношення бухгалтерського обліку та фінансової } \\
\text { звітності }\end{array}$ \\
\hline \multicolumn{3}{|c|}{ Методичний сектор } \\
\hline $\begin{array}{l}\text { Методи оцінки активів та } \\
\text { зобов'язань }\end{array}$ & $\begin{array}{l}\text { Положення про управління. } \\
\text { Облікова політика }\end{array}$ & $\begin{array}{l}\text { Вибір методу оцінки активів та зобов'язань; вибір } \\
\text { амортизаційних методів основних засобів; вибір методів } \\
\text { оцінки поточних активів }\end{array}$ \\
\hline $\begin{array}{l}\text { Метод розрахунку } \\
\text { вартості виробництва та } \\
\text { ціни }\end{array}$ & $\begin{array}{l}\text { Положення про управління. } \\
\text { Облікова політика. } \\
\text { Положення нормативних актів щодо } \\
\text { ціни }\end{array}$ & $\begin{array}{l}\text { Класифікатор витрат. } \\
\text { Класифікатор структури та складу статей оцінок та } \\
\text { розрахунків }\end{array}$ \\
\hline Формат бюджетів & $\begin{array}{l}\text { Положення про бюджетування. } \\
\text { Альбоми форм первинних документів } \\
\text { та господарської звітності }\end{array}$ & $\begin{array}{l}\text { Структура та склад бюджетів. } \\
\text { Класифікації документів за типом та видами. } \\
\text { Реєстр доповідей управління. } \\
\text { Порядок формування звітності } \\
\end{array}$ \\
\hline $\begin{array}{l}\text { Система обліку } \\
\text { аналітичних показників } \\
\text { для стратегічного, } \\
\text { тактичного та } \\
\text { оперативного управління } \\
\end{array}$ & Положення про аналіз управління & $\begin{array}{l}\text { Набір ключових показників ефективності. } \\
\text { Діапазон фінансових та нефінансових показників для } \\
\text { кожного центру відповідальності. } \\
\text { Процедури моніторингу обліково-аналітичних показників }\end{array}$ \\
\hline $\begin{array}{l}\text { Процедури організації } \\
\text { управлінського контролю }\end{array}$ & $\begin{array}{l}\text { Регламент (інструкції) проведення } \\
\text { інвентаризації на складі, магазинів, } \\
\text { робочих місць. } \\
\text { Регламент (інструкція) про } \\
\text { відповідальність окремих осіб, } \\
\text { пов'язаних із зберіганням, } \\
\text { переміщенням та використанням } \\
\text { внутрішнього інвентарю }\end{array}$ & $\begin{array}{l}\text { Набір орієнтирів, що використовуються для вимірювання } \\
\text { продуктивності. } \\
\text { кожного центру відповідальності. } \\
\text { Порядок формування нормальних значень орієнтирів. } \\
\text { Порядок визначення фактичних значень орієнтирів. } \\
\text { Порядок оцінки на основі аналізу даних діяльності центрів } \\
\text { відповідальності }\end{array}$ \\
\hline
\end{tabular}

Джерело: авторська розробка. 
Таблиця 2. Класифікація внутрішніх стандартів управлінського обліку

\begin{tabular}{|l|l|l|}
\hline Тип документа & \multicolumn{1}{|c|}{ Зміст } & \multicolumn{1}{|c|}{ Функції } \\
\hline $\begin{array}{l}\text { Інструктивно- } \\
\text { детодична }\end{array}$ & $\begin{array}{l}\text { Детальні напрями, які } \\
\text { розкривають облікову } \\
\text { політику та мають керівний } \\
\text { та навчальний характер }\end{array}$ & $\begin{array}{l}\text { Описує ділові операції } \\
\text { максимальними конкретними } \\
\text { заняттями: графічні рахунки, } \\
\text { вибір субконто, а також } \\
\text { процедура розрахунку суми } \\
\text { та величини змінних }\end{array}$ \\
\hline $\begin{array}{l}\text { Регуляторна } \\
\text { документація }\end{array}$ & $\begin{array}{l}\text { Різні довідники та } \\
\text { класифікатори, структура та } \\
\text { склад витрат та доходів, } \\
\text { бюджетна та бухгалтерська } \\
\text { структура тощо }\end{array}$ & $\begin{array}{l}\text { Встановлює правила для груп } \\
\text { онопипих деталей }\end{array}$ \\
\hline $\begin{array}{l}\text { Регулююча } \\
\text { документація }\end{array}$ & $\begin{array}{l}\text { Процедурний документ 3 } \\
\text { метою управління } \\
\text { бухгалтерським обліком, } \\
\text { альбомом уніфікованих форм } \\
\text { бухгалтерських та звітних } \\
\text { документів }\end{array}$ & $\begin{array}{l}\text { Визначає правила, } \\
\text { процедури, встановлення } \\
\text { бізнес-процесів, які описують } \\
\text { цикл бухгалтерського } \\
\text { процесу }\end{array}$ \\
\hline
\end{tabular}

Джерело: авторська розробка.

рівнях управління, а також запропонувала додати до системи управлінського обліку трансфертне ціноутворення та контроль над трансакційними витратами [8].

\section{META CTATTI}

Метою статті $€$ системне дослідження, критична оцінка теоретичних положень та діючої практики управлінського обліку.

\section{ВИК ААА ОСНОВНОГО МАТЕРІААУ АОС $\triangle$ IАЕННЯ}

Бухгалтерський облік повинен мати корпоративний статус з урахуванням принципів обліку всіх сегментів та видів діяльності підприємства. Управлінські стандарти бухгалтерського обліку повинні бути побудовані з метою забезпечення релевантної, об'єктивної та адекватної інформації для потреб керівництва та власників підприємства.

Управлінська бухгалтерська політика повинна включати аспекти: організаційні, технічні та методичні. Організаційна частина окреслює способи організації процесу функціонування бухгалтерсько-аналітичних процедур, у методичній частині - способи генерації інфрормації з метою формування балансу управління та звіту про управління відповідно до даних прибутків та збитків, та підготовка інфрормації для різних внутрішніх груп зацікавлених осіб. Технічна частина включає опис технічних засобів, які забезпечує ефективне функціонування системи бухгалтерського обліку.

Таким чином, поточна система бухгалтерського управлінського обліку повинна включати:

- раціональна структура внутрішнього контролю за центрами фрінансової звітності, бізнес-процесів, бізнес-сегментів;

- оцінка та бюджети для всієї структури управління з інструкціями, що описують формування та фрункціонування;

- схема рахунків управлінського обліку, яка адаптована до структури внутрішнього управління;

- методичні керівні принципи для приближення системи управлінського обліку відповідно до гармонізованої схеми рахунків;

- форми внутрішніх звітів та керівних принципів для їх відшкодування, звітності та аналізу;
- методи оцінки витрат, бухгалтерського обліку та аналізу відхилень від норм виконавців;

- методи розрахунку на основі прямих та загальних витрат до розподілу видатків за допомогою функції;

- методи трансфертного ціноутворення.

Під час розроблення Положення про управлінський облік на підприємстві необхідно врахувати такі структури:

- фрінансова структура організації та проєктування організаційної структури, керівництва та структуру відділу, який буде займатися управлінським обліком та контролем, стандартами потоків документації;

- технічний розділ - способи використання автоматизації бухгалтерського обліку (єдина автоматизована система для фінансового та управлінського обліку, але з різною системою рахунків або різними програмними продуктами);

- методичний розділ - способи використання системи рахунків (окрема або інтегрована система), методи оцінки активів та зобов'язань, метод розрахунку виробничих витрат та ціноутворення, фрорматів, бюджетів та внутрішньої (управлінської) звітності системи бухгалтерського обліку та аналітичні показники для стратегічних, тактичних та оперативних процедур управління.

У таблиці 1 розглянуто комплекс елементів управлінської облікової політики, що визначають процедурні.

У практичній діяльності підприємств існують різні варіанти дефініцій: правила бухгалтерського обліку, правила управління бухгалтерським обліком та бюджетом, управління бухгалтерськими засобами, внутрішні стандарти, корпоративні стандарти тощо.

Незалежно від форми, стандарти управлінського за змістом $€$ заключним етапом формулювання системи бухгалтерського обліку та безпосередньо визначаються параметрами та процедурами бухгалтерського обліку, а також кінцевою метою - звітність користувачеві з презентацією показників у правильних форматах для прийняття управлінських рішень. Обсяг та зміст внутрішніх стандартів залежить від проблем, які повинні бути вирішені з використанням системи бухгалтерського обліку. Всі стандарти та правила можна розділити на декілька груп (табл. 2).

Розвиток стандартів та правил управлінського обліку базується на етапах: підготовка уніфрікованих кла- 
сифрікацій та довідкових книг; розробка схеми управління рахунками; створення системи звітності управління.

Існують такі етапи формування внутрішніх стандартів управлінського обліку:

1. Розробка загальних класифікацій та довідкових книг класифікації управлінського обліку необхідна для систематизації та опису характеристик різних об'єкти обліку з метою унікальної інтерпретації всіх учасників планування, організації та контролю підприємства: класифрікатор основних засобів, класифікатор матеріалів, довідники діапазону (товари / роботи / послуги), довідники доходів /витрат, довідник з відповідальності, каталог підрядників, довідкові ціни тощо.

2. Розробка структури управління рахунками. Графрік управління рахунками виконує функцію наповнення бюджетних та бухгалтерських процедур при розробці управлінських бухгалтерських стандартів. Особливе значення приділяється структурі та фрормату рахунків. Розробка структури управління рахунком дозволяє максимально використовувати інформаційні ресурси управлінського обліку для підготовки додаткової інформації, яка розкриває основні показники звітів щодо конкретних потреб внутрішніх користувачів.

3. Формування системи управлінської звітності. Форма та зміст управлінських звітів у кожному випадку впливають не тільки на організаційний домен, а й на запити керівників. На додаток до звітів верхнього рівня (баланс управління, звіт про управління прибутку та збитку, та рух грошових коштів), пакет рахунків управлінських рахунків може включати декілька звітів, які мають такі класифікаційні ознаки: за призначенням, адресатом, фрормою тощо. Звітність повинна відображати інтереси як керівників, так і власників підприємства з метою запобігання асиметрії інфрормації.

\section{ВИСНОВКИ}

Стандарти управлінського обліку, які розроблені для конкретного суб'єкта підприємницької діяльності, мають бути наближені до конкретних потреб підприємства та спрямовані на підвищення ефективності системи управлінського обліку.

Управлінський облік підтримує прийняття рішень, надаючи керівникам відповідної інформації та аналізу щодо виконання, витрат та переваг певної операції. Крім того, зосереджуючись на фрінансовій інформації, бухгалтерський облік також повинен зосереджуватися на нефінансовій інформації.

Перспективами подальших досліджень є: розробка відповідної документації для кожного сектору облікової політики управлінського обліку, розробка графіку документації управлінського обліку тощо.

\section{Література:}

1. Костякова А.А. Управлінський облік як джерело інформаційного забезпечення системи управління. Молодий вчений. 2017. № 1. С. 49-54.

2. Дерій В.А., Гуменна-Дерій М.В. Управлінський облік і аналіз бізнес-процесів у підприємстві. Проблеми теорії та методології бухгалтерського обліку, контролю іаналізу. 2018. № 2 (40). С. 12-18.
3. Турова Л.Л., Костюнік О.В. Проблеми впровадження управлінського обліку в Україні. Інвестиції: практика та досвід. 2018. № 5. С. $37-40$.

4. Сирцева С.В., Кушнірук В.С., Бондаренко І.О. Управлінський облік як основа контролінгу в системі управління аграрними підприємствами. Інфраструктура ринку. 2019. № 31. С. 763-767.

5. Мазіна О.І. Значення глобальних принципів управлінського обліку у розвитку теорії, практики і професійних компетенцій. Економічний вісник. Серія: фрінанси, облік, оподаткування. 2018. № 2. С. 83-90.

6. Костюченко В.М., Малиновська А.М., Мамонова А.В. Генезис управлінського обліку в умовах перманентних змін. Економіка і суспільство. 2018. № 18. C. $933-942$.

7. Яременко Л.М., Пономаренко Я.А. Сучасні тенденції впровадження управлінського обліку із застосуванням міжнародного досвіду. "Вісник ЖДТУ": Економіка, управління та адміністрування. 2019. № 2 (88). С. $144-148$.

8. Волковська Я.В. Огляд підходів до організації управлінського обліку на підприємстві. Економічний вісник Запорізької державної інженерної академії. 2017. № 2 (2). С. $109-112$.

References:

1. Kostiakova, A.A. (2017), "Management accounting as a source of information of management system", Molodyi vchenyi, vol. 1, pp. 49-54.

2. Derii, V.A. and Humenna-Derii, M.V. (2018), "Management accounting and analysis of business processes in the enterprise", Problemy teorii ta metodolohii bukhhalterskoho obliku, kontroliu i analizu, vol. 2 (40), pp. $12-18$.

3. Turova, L.L. and Kostiunik, O.V. (2018), "Problems of management accounting organization in the ukrainian enterprises", Investytsii: praktyka ta dosvid, vol. 5, pp. $37-40$.

4. Syrtseva, S.V., Kushniruk, V.S. and Bondarenko, I.O. (2019), "Management accounting as the basis of controlling in the management system of agrarian enterprises", Infrastruktura rynku, vol. 31, pp. 763-767.

5. Mazina, O.I. (2018), "The importance of global principles of management account in the development of theory, practice and professional competences", Ekonomichnyi visnyk. Seriia: finansy, oblik, opodatkuvannia, vol. 2, pp. 83-90.

6. Kostiuchenko, V.M., Malynovska, A.M. and Mamonova, A.V. (2018), "Genesis of managerial accounting in permanent changes conditions", Ekonomika i suspilstvo, vol. 18, pp. 933-942.

7. Yaremenko, L.M. and Ponomarenko, Ya.A. (2019), "Modern trends in the implementation of managerial accounting with the application of international experience", "Visnyk ZhDTU": Ekonomika, upravlinnia ta administruvannia, vol. 2 (88), pp. 144-148.

8. Volkovska, Ya.V. (2017), "Research of the approaches to the management accounting organization at the enterprise", Research of the approaches to the management accounting organization at the enterprise, vol. 2 (2), pp. 109-112.

Стаття надійшла до редакиї 06.08.2021 p. 